\title{
Alcohol consumption and risky sexual practices: the pattern of nursing students from the Spanish University
}

\author{
Eugenia Gil-García ${ }^{1}$ \\ Jussara Gue Martini² \\ Ana Maria Porcel-Gálvez ${ }^{1}$
}

Objective: to determine the prevalence of substance abuse and unsafe sexual practices and to analyze the relationship between them, in nursing students at the University of Seville. Method: quantitative methodological approach with a descriptive cross-sectional design. The population was composed of first year nursing students in the University of Seville, during the academic year 2010-2011 ( $N=510)$, with consecutive opportunistic sampling composed of students who attended class on the scheduled day $(n=291)$. Results: a high prevalence of alcohol consumption, and increased likelihood of not using protective measures during sexual practices when alcohol had been consumed, was present. Conclusion: these findings are consistent with those obtained in the same population in Brazil, and highlight the need to strengthen in the nursing curriculum, the transverse axis related to the prevention of substance abuse, especially alcohol.

Descriptors: Students, Nursing; Education, Nursing; Relative Risk (Public Health); SubstanceRelated Disorders.

${ }^{1} \mathrm{PhD}$, Associate Professor, Departamento de Enfermería, Universidad de Sevilla, Sevilla, Spain.

2 PhD, Adjunct Professor, Centro de Ciências da Saúde, Universidade Federal de Santa Catarina, Florianópolis, SC, Brazil. 


\section{Introduction}

Numerous authors have shown that the university setting favors the onset and consolidation of certain risk behaviors, especially those related to toxic substance use and unprotected sex practices ${ }^{(1-3)}$. However, these behaviors are not perceived by students as being risky ${ }^{(4-6)}$. Research shows a positive relationship between the perceived risk, the prevalence of toxic consumption ${ }^{(7)}$ and the interaction between different risk behaviors ${ }^{(8-10)}$. Thus, using drugs increases the probability of living through a driving-related risk situation(11), and having sex without protection ${ }^{(12-13)}$.

In Spain, in 2007, alcohol consumption and unprotected sexual practices among young people showed alarming figures: $32 \%$ of young people between 15 and 34 years had been drunk at some time during the last month(14), and $16 \%$ had unprotected sex ${ }^{(15)}$.

In Brazil, we found few studies that dealt with risky sexual practices among university students, but we did find studies relating to toxic substance consumption. Prevalence studies conducted in São Paulo, in 2008, showed a significant increase in the consumption of alcohol and tobacco(16), demonstrating a strong association between alcohol consumption and recklessness in traffic accidents, more frequently in people younger than 25 years $^{(17)}$. At the University of Curitiba, in 2007, the prevalence of alcohol consumption one or more times per week in the last 30 days, was $26.5 \%$ in physiotherapy students, and $31.5 \%$ in physical education students ${ }^{(18)}$.

In national research about alcohol and other drug consumption by Brazilian university students in 27 venues of the provinces across the country, the data presented indicated a startling fact: almost $49 \%$ of college students surveyed had tried an illicit drug at least once in their lives and $80 \%$ of respondents under age 18 reported that they had already consumed some kind of alcoholic beverage. The consumption of alcohol, tobacco and other drugs among university students is more common than in the general population, which reinforces the need for greater understanding of the phenomenon for the development of prevention in this segment ${ }^{(19)}$.

Reviewing other studies in Latin America, we found that in Colombia, $28.5 \%$ of university students consumed alcohol at least once a week, and $51.7 \%$ consumed it occasionally(20). Thus, the most widely used drug among students in Cali, in 2006, was alcohol $(74.5 \%$ consuming it regularly), with the most common beverages being, in this order, beer, spirits and wine(21); and at the University of Salvador, Chile alcohol (74.7\%) and tobacco (16.6\%) were the major drugs of initiation(6).

Given that during the university period the risk behaviors are consolidated and nursing students, future health team members, have a key role in health education and the development and implementation of preventive measures(22), our objective focused on determining the prevalence of toxic substance use and unprotected sexual practices of nursing students from the University of Seville. Knowing the sociodemographic profile and risk practices helps us, as teachers, to address the teaching process of students as promoters of health, and as researchers, to learn some of the mechanisms at work favoring the disruption between perception and behavior.

\section{Method}

This was a cross-sectional study. The study environment was the University of Seville. The population was composed of first year nursing students enrolleed in Colleges and Schools of the University of Seville District, during the academic year of 2010-2011 ( $N=510)$.

Non-probability $(n=291)$, opportunistic and consecutive sampling of the entire population susceptible of being selected was used, selecting all students attending class on the scheduled day in the months of February and March of 2011.

The information was collected using a selfadministered questionnaire developed ad hoc, after the review of the literature and consultation with experts, which conferred its face and content validity. Ethical requirements were followed, as referred to in Spanish law, Law 15/1999 of December the $13^{\text {th }}$. The data were treated anonymously and confidentially. Prior to the start of the questionnaire, all students received written information about the aims, purpose and project financing, as well as the voluntary, anonymous and confidential nature of the data and of their ability to withdraw their collaboration voluntarily, or of the possibility of correcting or cancelling their personal data at any time.

The variables were: sociodemographic characteristics, use of toxic substances and risky sexual practices. For statistical analysis we used SPSS 15.0 for Windows, working at a significance level of $p$ $<0.05$. Exploratory analysis was performed to obtain the distribution of frequencies and proportions, measures of central tendency, dispersion and confidence intervals in continuous variables, and the chi-square test with Fisher correction in the bivariate analysis of qualitative variables. To detect clusters of toxic consumption and 
of risky sexual practices we conducted a principal component factor analysis and Varimax rotation. To identify the weight that gender, age and/or drug consumption had in using or not using protective measures in sexual practices, a binary logistic regression analysis was conducted.

\section{Results}

\section{Sociodemographic Profile}

Of the 291 individuals who completed the questionnaire, $20 \%$ were male $(n=51)$ and $80 \%$ female $(n=240)$, with an age range of $18-50$ years. The average age was 21 years. Eighty-one percent of students came from urban areas. Forty-two percent of male students and $50 \%$ of female students had never done paid work.

Twenty-nine percent of fathers and 3\% of mothers had university studies. Nine percent of parents of students were engaged in health professions. Thirty-five percent of mothers and $0.4 \%$ of fathers were considered to be a "housewife".

\section{Toxic Substance Consumption}

To analyze risk behavior, we asked about use of toxic substances (tobacco, beer, wine, combinations, marijuana, tranquilizers and cocaine).

It was considered that the subject consumed "Sometimes" when it happened less than two times a week, "usually" when consumed twice a week.

Our results indicated a high habitual consumption of tobacco ( $26 \%$ women versus $17 \%$ of men), drinks mixed with alcohol ( $50 \%$ men versus $38 \%$ women), beer ( $31 \%$ men and $20 \%$ women), wine ( $19.6 \%$ versus $17 \%$ women) and hashish ( $6 \%$ men and $2 \%$ women). They sometimes consumed tranquilizers ( $14 \%$ of men versus $8.5 \%$ of women). Gender differences were statistically significant in relation to consumption of beer $(0.016)$ (Table 1).

Table 1 - First year nursing students enrolled in District Colleges and Schools of the University of Seville, according to the values of consumption, toxic and sex, Seville, Spain, 2010-2011

\begin{tabular}{lccccccc}
\hline & \multicolumn{2}{c}{ Male } & & \multicolumn{2}{c}{ Female } & p-value \\
\cline { 2 - 3 } \cline { 6 - 7 } & $\mathbf{n}$ & $\%$ & & $\mathbf{n}$ & $\%$ & \\
\hline Tobacco & 23 & 45.10 & & 103 & 42.90 & \\
$\quad$ Never & 19 & 37.30 & & 74 & 30.80 & \\
Sometimes & 9 & 17.60 & & 63 & & 26.30 & \\
Usually & & & & & & & (continue...)
\end{tabular}

Table 1 - (continuation)

\begin{tabular}{|c|c|c|c|c|c|}
\hline & \multicolumn{2}{|c|}{ Male } & \multicolumn{2}{|c|}{ Female } & \multirow{2}{*}{ p-value } \\
\hline & $\mathbf{n}$ & $\%$ & $\mathbf{n}$ & $\%$ & \\
\hline Beer & & & & & 0.016 \\
\hline Never & 9 & 17.60 & 98 & 40.80 & \\
\hline Sometimes & 26 & 51.00 & 93 & 38.80 & \\
\hline Usually & 16 & 31.40 & 48 & 20.00 & \\
\hline Wine & & & & & 0.538 \\
\hline Never & 19 & 37.30 & 74 & 31.10 & \\
\hline Sometimes & 22 & 43.10 & 123 & 51.70 & \\
\hline Usually & 10 & 19.60 & 41 & 17.20 & \\
\hline \multicolumn{2}{|c|}{ Combined with alcohol } & & & & 0.206 \\
\hline Never & 8 & 16.00 & 35 & 14.90 & \\
\hline Sometimes & 17 & 34.00 & 111 & 47.20 & \\
\hline Usually & 25 & 50.00 & 89 & 37.90 & \\
\hline Hashish & & & & & 0.153 \\
\hline Never & 36 & 72.00 & 197 & 83.10 & \\
\hline Sometimes & 11 & 22.00 & 34 & 14.30 & \\
\hline Usually & 3 & 6.00 & 6 & 2.50 & \\
\hline Tranquilizers & & & & & 0.435 \\
\hline Never & 43 & 86.00 & 215 & 91.10 & \\
\hline Sometimes & 7 & 14.00 & 20 & 8.50 & \\
\hline Usually & 0 & 0.00 & 1 & 0.40 & \\
\hline Cocaine & & & & & 0.561 \\
\hline Never & 50 & 100.00 & 233 & 98.70 & \\
\hline Sometimes & 0 & 0.00 & 3 & 1.30 & \\
\hline Usually & 0 & 0.00 & 0 & 0.00 & \\
\hline
\end{tabular}

The principal components of the factor analysis, which explained $61 \%$ of the variance, with $\mathrm{KMO}$ of 0.645 and sig. 0.000, grouped consumption in three factors: F1: Alcohol Consumption; F2: Stimulant Drugs; F3: Relaxant Drugs. As shown in the rotated component matrix of the factor analysis, tobacco was associated with the consumption of alcohol and relaxant drugs and hashish consumption shared an association with relaxant and stimulant drugs (Table 2 ).

Table 2 - First year nursing students enrolled in District Colleges and Schools of the University of Seville, according to the variables factor, toxic substance consumption, Seville, Spain, 2010-2011

\begin{tabular}{lccc}
\hline & \multicolumn{3}{c}{ Factor Components } \\
\cline { 2 - 4 } Consumption & Alcohol & $\begin{array}{c}\text { Stimulant } \\
\text { Drugs }\end{array}$ & $\begin{array}{c}\text { Relaxant } \\
\text { Drugs }\end{array}$ \\
\hline Combined & 0.746 & & \\
Beer & 0.737 & & \\
Wine & 0.705 & 0.866 & \\
Ecstasy & 0.849 & 0.839 \\
Cocaine & & \\
Tranquilizers & & & 0.509 \\
Tobacco & & \\
Hashish & & \\
\hline Extraction Method: Principal Component Analysis. Varimax
\end{tabular}




\section{Unprotected Sexual Practices}

With regard to sexual practices we observed that the use of condoms was common practice for $65 \%$ of women and $55 \%$ of men. And, "withdrawal" had been used sometimes by $45 \%$ of men and $47 \%$ of women. Thirty-two percent of women had used the MorningAfter Pill (Table 3).

Table 3 - First year nursing students enrolled in District Colleges and Schools of the University of Seville, according to the values, sexual behaviors and protection measures, Seville, Spain, 2010-2011

\begin{tabular}{|c|c|c|c|c|}
\hline & \multicolumn{4}{|c|}{ Gender } \\
\hline & \multicolumn{2}{|c|}{ Male } & \multicolumn{2}{|c|}{ Female } \\
\hline & $\mathbf{n}$ & $\%$ & $\mathrm{n}$ & $\%$ \\
\hline \multicolumn{5}{|l|}{ Condoms } \\
\hline Never & 3 & 6.70 & 9 & 4.40 \\
\hline Occasionally & 17 & 37.80 & 63 & 30.90 \\
\hline Always & 25 & 55.60 & 132 & 64.70 \\
\hline \multicolumn{5}{|c|}{ Oral Contraceptives } \\
\hline Never & 25 & 65.80 & 101 & 59.80 \\
\hline Occasionally & 8 & 21.10 & 29 & 17.20 \\
\hline Always & 5 & 13.20 & 39 & 23.10 \\
\hline \multicolumn{5}{|l|}{ Spermicides } \\
\hline Never & 32 & 91.40 & 142 & 92.80 \\
\hline Occasionally & 2 & 5.70 & 10 & 6.50 \\
\hline \multirow[t]{2}{*}{ Always } & 1 & 2.90 & 1 & 0.70 \\
\hline & & & \multicolumn{2}{|c|}{ (continue. } \\
\hline
\end{tabular}

Table 3 - (continuation)

\begin{tabular}{|c|c|c|c|c|}
\hline & \multicolumn{4}{|c|}{ Gender } \\
\hline & \multicolumn{2}{|c|}{ Male } & \multicolumn{2}{|c|}{ Female } \\
\hline & $\mathrm{n}$ & $\%$ & $\mathbf{n}$ & $\%$ \\
\hline \multicolumn{5}{|l|}{ Withdrawal } \\
\hline Never & 22 & 55.00 & 84 & 51.90 \\
\hline Occasionally & 16 & 40.00 & 71 & 43.80 \\
\hline Always & 2 & 5.00 & 7 & 4.30 \\
\hline \multicolumn{5}{|c|}{ Vaginal Rings or Patches } \\
\hline Never & 31 & 88.60 & 135 & 86.50 \\
\hline Occasionally & 2 & 5.70 & 8 & 5.10 \\
\hline Always & 2 & 5.70 & 13 & 8.30 \\
\hline \multicolumn{5}{|c|}{ Morning-After Pill } \\
\hline Never & 30 & 83.30 & 104 & 68.40 \\
\hline Occasionally & 6 & 16.70 & 48 & 31.60 \\
\hline Always & 0 & 0.00 & 0 & 0.00 \\
\hline \multicolumn{5}{|c|}{ Diaphragm or IUD } \\
\hline Never & 35 & 97.20 & 147 & 98.70 \\
\hline Occasionally & 0 & 0.00 & 0 & 0.00 \\
\hline Always & 1 & 2.80 & 2 & 1.30 \\
\hline
\end{tabular}

The principal components factor analysis related to sexual practices indicated that there were three factors explaining $69.082 \%$ of the variance with a KMO of 0.547 , sig. 0.00. The factors were: F1: Do not use protective measures; F2: Chemical protection measures; and, F3: Barrier measures. As shown in the rotated components, condom use was negatively associated with use of protective measures and with the use of other barrier measures (Table 4).

Table 4 - First year nursing students enrolled in District Colleges and Schools of the University of Seville, according to the values, protection measures, Seville, Spain, 2010-2011

\begin{tabular}{lccc}
\hline & & Factor Components & \\
\cline { 2 - 4 } & No measure & Chemical Protection & Barrier Protection \\
\hline None & 0.827 & & \\
Withdrawal & 0.799 & & 0.455 \\
Condoms & 0.626 & 0.81 & \\
Diaphragm or IUD & & 0.781 & 0.926 \\
Creams & & & \\
Vaginal Rings or Patches & & & \\
\hline
\end{tabular}

Extraction Method: Principal Component Analysis. Varimax

\section{Relationship between alcohol consumption and protective measures}

To determine whether age, sex and use of toxic substances influenced or not the use of protection measures, a Binary Logistic Regression Model (BLR) was built in steps in which we dichotomized the independent variable (IV) in measures of protection: Yes : 1/No: 0. Age, gender (male: 1, female: 0), "Alcohol", "Stimulant Drugs" and "Relaxant Drugs" were introduced as covariables.

Initially age was introduced, followed by the categorical variable gender, and continuing with the factors obtained in the factor model on the consumption 
of toxic substances (F1: "Alcohol Consumption", F2: "Stimulant drugs" and F3: "Relaxant Drugs"). The analysis included 243 cases (Table 5).

The results indicated that the variable that influenced the use or non-use of protective measures was "Alcohol Consumption" (0.001); age, gender and the consumption of "Stimulant drugs" and "Relaxant drugs" were left out of the equation, as they had no statistical significance. The Likelihood Ratio (0.005) and the Hosmer-Lemeshow statistic $(0.567)$ revealed the goodness of the fit of the model. The coefficients of determination showed the amount of variance explained by the model, in our case we obtain a correct classification rate of $67.1 \%$. The OR value of $\operatorname{Exp}(B)$ associated with alcohol consumption indicated that consuming alcohol increased the likelihood of not using protective measures by 1.617 . In other words, the relative risk of not using protective measures was multiplied by 1.6 times when alcohol was consumed.

Table 5 - First year nursing students enrolled in District Colleges and Schools of the University of Seville, Binary Logistic Regression Model "Protection Measures", Seville, Spain, 2010-2011

\begin{tabular}{|c|c|c|c|c|c|c|c|c|}
\hline & PredictorB & Error & Type & Wald & gl & Sig & OR $\operatorname{Exp}(B)$ & $\mathrm{Cl}(95 \%)$ \\
\hline Constant & -1.481 & 0.701 & 4.472 & 1 & 0.034 & 0.227 & & \\
\hline Age & 0.043 & 0.031 & 1.901 & 1 & 0.168 & 1.044 & 0.982 & 1.109 \\
\hline Gender & 0.601 & 0.392 & 2.345 & 1 & 0.126 & 0.548 & 0.254 & 1.183 \\
\hline "Alcohol Consumption" & 0.481 & 0.145 & 11.068 & 1 & 0.001 & 1.617 & 1.218 & 2.147 \\
\hline "Stimulant Drugs" & 0.263 & 0.2 & 1.739 & 1 & 0.187 & 1.301 & 0.88 & 1.924 \\
\hline "Relaxant Drugs" & 0.005 & 0.136 & 0.001 & 1 & 0.97 & 1.005 & 0.769 & 1.313 \\
\hline \multicolumn{3}{|c|}{ Model } & \multicolumn{2}{|c|}{$X^{0}$} & \multicolumn{2}{|c|}{ gl } & \multicolumn{2}{|c|}{ Sig } \\
\hline Likelihood ratio & & & \multicolumn{2}{|c|}{16.56} & \multicolumn{2}{|c|}{5} & \multicolumn{2}{|c|}{0.005} \\
\hline Hosmer and Lemeshow & & & \multicolumn{2}{|c|}{6.719} & \multicolumn{2}{|c|}{8} & \multicolumn{2}{|c|}{0.567} \\
\hline
\end{tabular}

Cox R Snell square of 0.066 and 0.090 Nagelkerke Correct classification rate of $67.1 \%$

\section{Discussion}

Nursing students at the University of Seville had a similar profile to other college students ${ }^{(9-23)}$ and, just as occured in Spanish society ${ }^{(14)}$, they showed problematic alcohol consumption. The young nursing students usually consumed alcoholic beverages, and alcohol consumption favored carrying out other risk behaviors such as not using protective measures during sexual intercourse.

Today in the Western countries, we live in a climate of concern about consumption of illegal, toxic substances; in civil society there has been strong pressure, amplified by the mass media for preventing the use of illegal drugs, and a state that brings a great quantity of money to repression, education and treatment. We live with a gigantic illegal power of producers and vendors of illegal substances that continue to make efforts to popularize their products. In Brazil, alcohol is responsible for $90 \%$ of hospitalizations and $50 \%$ of victims of violent death in metropolitan regions ${ }^{(24)}$. But little reflection is made upon excessive alcohol consumption and its tendency to grow. We consider it necessary to remember that the majority of admissions for drugs are due to alcohol and that most violent deaths (homicides, suicides and traffic accidents) are related to alcohol abuse ${ }^{(24)}$. In many research studies, the relation between alcohol consumption and traffic accidents is revealed ${ }^{(11-13)}$; our data highlights the relation between alcohol consumption and risky sexual practices.

The results of the research present us with great challenges as researchers and as teachers. We believe that the results should contribute to a warning to the academic community of the risks of alcohol consumption, especially in young people who, in the immediate future, will be part of health teams. Therefore, we consider it appropriate to strengthen in the nursing curriculum a transverse axis related to the prevention of toxic substances(5) and in particular, with alcohol(22). The approach must be made from an integrated perspective, relating it to the care of the quality of life of the communities, not to mention the complexity of factors that surround its production, distribution and marketing(25).

\section{Conclusion}

The results, as was the case with young Latin American university students, showed a high prevalence of use of tobacco and alcohol, and revealed the multiplier effect that consuming alcohol produced in not using protective measures during sexual intercourse. 
Therefore, as nursing teachers we consider it convenient to incorporate a preventive axis related to substance abuse, and especially with alcohol consumption into the academic curriculum of future health professionals.

\section{References}

1. Cunill M, Planes M, Grass ME. Creencias sesgadas respecto al grado de "dureza" de algunas drogas en estudiantes universitarios. Adicciones. 1998;10(3):233-8. 2. Font-Mayolas S, Grass ME, Planes M. Análisis del patrón de consumo de cannabis en estudiantes universitarios. Adicciones. 2006;18(4):337-44.

3. Jiménez-Muro A, Belmonte A, Marqueta A, Gargallo

$P$, Nerín de la Puerta I. Consumo de drogas en estudiantes universitarios de primer curso. Adicciones. 2009;21(1):21-8.

4. Espada JP, Pereira JR, García-Fernández JM. Influencia de los modelos sociales en el consumo de alcohol de los adolescentes. Psicothema. 2008;20(4):531-7.

5. Morales NB, Plazas M, Sánchez R, Arena CA. Risk and protection factors related to the consumption of psychoactive substances in undergraduate nursing students. Rev. Latino-Am. Enfermagem. 2011;19(spec):673-83.

6. Ortega-Pérez CA, Costa-Júnior $M L$, Pereira Vasters G. Epidemiological profile of drug addiction in college students. Rev. Latino-Am. Enfermagem. 2011;19(Spe):665-72.

7. Moral MV, Ovejero A. Análisis diferencial por niveles de edad de las actitudes hacia el consumo de sustancias psicoactivas en adolescentes españoles. Interam J Psychol. 2005;9(3):325-38.

8. Towards FA. Sociological Understanding of Youth and their Risk-taking. J Youth Stud. 2000;3(3):317-31.

9. Hernán M, Fernández M, y Ramos M. La salud de los jóvenes. Gac Sanit. 2004;18(1):47-55.

10. Arantes Wagner G, Andrade Stempliuk V, Zilberman M, Pereira Barroso L, Guerra de Andrade A. Alcohol and drug use among university students: gender differences. Rev Bras Psiquiatr. 2007;29(2):123-9.

11. Meneses Falco C, Gil García E, Romo Avilés N. Adolescentes, situaciones de riesgo y seguridad vial. Atenção Primaria. 2010;42(9):452-62.

12. Gil García E, González López R, Meneses Falco C. Percepción de riesgo y dinámicas promotoras de salud en adolescentes: una mirada de género. Rev Española Drog. 2010;35(3):297-308.

13. Guitart AM, Espelt A, Castellano $Y$, Bartroli $M$, Villalbí JR, Domingo-Salvan A, Brugal MT. Impacto del trastorno por consumo de alcohol en la mortalidad: ¿hay diferencias según la edad y el sexo? Gac Sanit. 2011;25(5):385-90.

14. Informe del Plan Nacional sobre Drogas. 2007. [acesso 2 dez 2011]; Disponível em: http:// www.pnsd.msc.es/Categoria2/observa/pdf/ InformeEdades2007-2008.pdf 1.

15. Informe Juventud en España [Internet]; 2008. [acesso 2 dez 2011]; Disponível em: http://www.injuve. es/contenidos. item. action?id=1531688780

16. Arantes Wagner G, Guerra de Andrade A. Uso de alcohol, tabaco e outras drogas entre estudantes universitarios brasileros. Psiq Clin. 2008;35(1):48-54.

17. Severo Santos J F, Santos Alves V. Perfil do estilo de vida relacionado á saúde dos acadêmicos da Unicentro, Campus Irati, PR. Efdeportes [Internet] fev 2009; [acesso 15 dez 2011]; Disponível em: http:// www.efdeportes.com/efd129/perfil-do-estilo-de-vidarelacionado-a-saude-dos-academicos.htm1.

18. Chiapetti N, Serbena, C A. Uso de álcool, tabaco e drogas por estudantes da área de saúde de uma universidade de Curitiba. Psicol Reflex Crit. 2007;20(2):303-13.

19. Presidência da República (BR). Secretaria Nacional de Políticas sobre Drogas. I Levantamento Nacional sobre o Uso de Álcool, Tabaco e Outras Drogas entre Universitários das 27 Capitais Brasileiras. Brasília: SENAD; 2010. 284 p.

20. Lema Soto LF, Salazar Torres IC, Varela Arévalo MT, Tamayo Cardona JA, Rubio Sarria A, et al. Comportamiento de salud de los jóvenes universitarios: satisfacción con el estilo de vida. Pensamiento Psicol. 2009;5(12):71-88.

21. Cáceres D, Salazar I, Varela M, Tovar J. Consumo de drogas en jóvenes universitarios y su relación de riesgo y protección con los factores psicosociales. Univ Psychol Bogotá (Colombia). 2006;5(3):521-34.

22 Silva SED da, Vilela EV, Padilha MIP de S, Martini JG, Schubert VMB. A educação em saúde como uma estratégia para enfermagem na prevenção do alcoolismo. Esc Anna Nery. 2007;11(4):699-705.

23. García de Albéñiz XA, Guerra Gutiérrez F, Ortega Martínez R, Sánchez Villegas A, Martínez González MA. Consumo de tabaco en titulados universitarios. El Proyecto SUN (Seguimiento Universidad de Navarra). Gac Sanit. 2004;18:108-17.

24. Carlini-Cotrim B, Gazal-Carvalho C, Gouveia N. Comportamentos de saúde entre jovens estudantes das redes pública e privada da área metropolitana do Estado de São Paulo. Rev Saúde Pública. 2000;4(6):636-45. 
25. Martini JG, Furegato AR. Teachers' social representations on drug use in a secondary school. Rev. Latino-Am. Enfermagem. 2008;16(Spe):128-34. 